\title{
The Dynamics Transformation of Public Policy Making in Indonesian Democracy
}

\author{
Andy Al Fatih \\ Universitas Sriwijaya (email: alfatihmpa@yahoo.com)
}

\begin{abstract}
Public policies are purposed, basically, to solve public problems and for the sake of public welfare. They should, therefore, be made thoughtfully, implemented successfully, and give pleasant impacts to the target groups. This article is related to the dynamics transformation of public policy making in indonesian democracy. In centralistic political system, national government (executive body) controlled more essential public affairs. As the result, most public policies were much engineered and directed, mostly, to the needs of the in power. The tendentious public policies were abused for personal, group, and cronies' interests of the in authority officials. The people were left behind, served as object of development, and stayed poor. It happened for decades. The people could not stand it any longer and struggled for a reformed government resulting in regional autonomy. Regional autonomy seems promising for the people's prosperity. In this era, legislative body tends to control power. The people set hopes and wait for happiness. In fact, some members of parliament only show power. They control many walks of lives. They represent themselves rather than the people. They somewhat abuse power and make public policies for their own gains. The people are left behind again and still get disappointed. Here, a paradox occurs. The paradox must be sorted out well. The hot discussion begins. The actors blame to one another.
\end{abstract}

\section{Keywords:}

Transformation; public policy; public problems; prosperity; legislative; executive; power; abuse

\section{Introduction}

In the history of Republic of Indonesia, there has been - at least - three regimes which has been in power. They are, old order regime, new order administration, and the ruler of the reformed order. Each in power regime has its own features. Firstly is Old Order Regime period 1959-1966. The government has been characterized by guided democracy (autocracy) in which the people's decisions must be in the frame of the leader's desire. In this kind of democracy, government propagandas play extremely significant roles to justify what Government did. 
The next regime is New Order Administration - period 1966 - 1998. This system applied Pancasila [five Indonesian principles] democracy in which decisions were engaged in much deliberation. Central government was extremely powerful. At that time, no opposition was allowed (Putri, 2020)

The latter regime, Reformed Order - which has been in practice since 1998 up to present time - styles "liberal" democracy. The control is much more on the hand of House of Representative (Legislative Body). It is at this time the regional autonomy is exercised.

\section{The Principle of Regional Autonomy}

In the academic work of Alfatih (2003) entitles "is regional autonomy a paradox?", there exists some information relating to the concept of regional autonomy. Concept of regional autonomy is understood (mainly by lower levels of governments and the people) as the delegation of political power rather than managerial delegation. The political power delegation implies that regional governments and the people have - politically, economically, and socially - absolute sovereignty towards the regions. It means that central government is forbidden to interfere all affairs of regional or local governments. The governments and the people think that they can do many things as they wish and are not compulsory to obey the central government. Understanding the concept of regional autonomy from this point of view, off course, is inappropriate. Therefore, there lies the mistakes. It is essential to take a note that Indonesia is a unity state. Regional autonomy is just a kind of the implementation of decentralization principle. Inherently, regional autonomy means managerial delegation, not political power delegation. Therefore, both central and regional governments share power. Some affairs are delegated to regional governments, others are under the control of central government. Fundamentally, a Governor - as a number one person in the region/province has two roles: as a representative of central government and as the Head of the region. As the latter, he has rights to govern, manage, and make use of resources in which the region has in "his ways" for the benefit of the people. Nevertheless, as a representative of central government, he does the main functions of central government towards lower level of governments - in the region. Such functions are as coordination, monitoring, stabilization, and evaluation. Therefore, central government is still able to get involved in the affairs of regional government. 
Regional autonomy must be understood as managerial delegation only. It means that central government delegates the management of regional governmental affairs to regional government. By this way, regional government has adequate authority to manage its own governance affairs and to make use of all resourses which it owns. Therefore, there are supposed to be more developments and more employments available. At this point, prosperity of the people tends to be able to become true. Concerning with decentralized government, Alvin Toffler - cited by Osborn and Gaebler (1993:251) - expressed himself “ one way is to attempt to further strengthen central government, adding more and yet more politicians, bureaucrats, experts, and computers in the desperate hope of outrunning the accelaration of complexity; the other is to begin reducing the decision load by sharing it with more people, allowing more decisions to be made "down below" or at the "periphery" instead of concentrating them at the already stressed and malfunctioning center." Moreover, the concept of autonomy reflects a concern to ensure and link the creation of the best circumstances for humans to develop their nature and express their diverse qualities, protection from the arbitrary use of political authority and coercive power, involvement of citizens in the determination of the conditions of their association, and expansion of economic opportunity to maximize the availability of resources. Autonomy connotes the capacity of human beings to reason self conciously, to be self reflective, and to be self determining. It involves the ability to deliberate, judge, choose, and act upon different possible courses of action in private as well as public life. Clearly, the idea of an "autonomous" person could not develop while political rights, obligations, duties were closely tied (Held, 1990:269-270).

\section{The Advantages of Regional Autonomy Principle}

There are, naturally, some advantages - for regional and local governments, the people, as well as central government - of applying the principle of regional autonomy. They are, among others:

1. Positive image, especially to central government, exists because regional autonomy impresses more democratic atmosphere.

2. Lower level governments can play more roles in development due to delegation of resources management from upper level government.

3. There will be more opportunities for the officials to realize their selves-actualization. 
4. The more guarantee of environmental sustainability.

5. Service delivery can be more down to earth.

6. There will be more prosperity for the people to be brought into reality.

7. In a unity state, Central government involvement stays still toward regional government, especially in forms of coordination, supervision, stabilization, allocation, distribution, and evaluation.

\section{The Nature of Public Policy}

Public policy, basically, refers to policies made by governments for the sake of public interest. According to Alfatih (2012), As far as public resources are concerned, public policy has become the infrastructure to make use of public resources. Without the policy, the utilization of public resources is considered unlawful. In his book entitling Implementasi Program dan Pemberdayaan Masyarakat or in English, Program Implementation and Community Empowerment, Alfatih (2010:2) claims public policy is purposed to protect public interest, solve public problem, give empowerment, as well as to bring social prosperity into reality. It is, therefore, the main stake holder of a policy, primarily, is public, the people. The content of a policy must be problem solving and empowering in nature. Therefore, according to Francine Rabitnovitz, et al, in Alfatih (2012), the implementation has to follow 3 principles. Namely:

1. Policy implementation must refer to what is said in the policy accurately

2. Policy implementation must be able to raise the commitment of the policy implementors.

3. Policy implementation must be able to fulfill public's wishes. Therefore, there must be a consensus between the implementor organization and prevailing political system.

\section{The Dynamics of Power Transformation of Executive and Legislative Bodies Relating to Public Policy Affairs}

Once upon a time, Alfatih expressed himself (2003), new order regime was in power, regional governments were powerless and the people were very suffering. At that time, centralistic system was in practice making central government was extremely powerful. 
Governments - the regional as well as the local ones - were just like "tootless tiger" - had hardly any power in making political decisions as well as to make use of their resources for "their people". They were very much in command of the central. Governors were pointed rather than elected. Bureaucracy was politized. It was very much interfered by political considerations. In placing bureaucrats in positions, parochialism approach was applied. Politics was also bureaucraticized. Political engineering was frequently taken place. Regional and local bureaucrats had to obey and listen to the will of the central. Officials from central government were extremely "respected" and well served. They were very much frightened. This kind of attitudes had been "standardized" and common. They should be exercised, unless, firing, replacement, warning or any kinds of sanctions could be taken place against "the stubborn". Putri (2020) claimed "the main vision of the New Order government was to implement Pancasila and the 1945 Constitution purely and consistently in every aspect of the life of Indonesian society. With this vision, the New Order provided a glimmer of hope for the Indonesian people. But the reality is that Pancasila Democracy is the same as a dictatorship. The pure and consistent implementation of Pancasila values only become the political instrument of the ruler.

This can be seen from the political characteristic of the New Order period".

Table 1.

The Description of The Characteristic of Public Policy in New Order Regime

\begin{tabular}{|c|c|c|c|c|}
\hline $\begin{array}{c}\text { Stages of Public } \\
\text { Policy Process }\end{array}$ & The Actor & Treatment & Benefit Receiver & Remark \\
\hline $\begin{array}{l}\text { Policy } \\
\text { Formulation }\end{array}$ & Executive & $\begin{array}{l}\text { tend to be inaccurate, } \\
\text { have a little feasibility } \\
\text { study. }\end{array}$ & $\begin{array}{l}\text { Government } \\
\text { (Executive), some } \\
\text { (high rank) officials, } \\
\text { and the people. }\end{array}$ & $\begin{array}{l}\text { Personal/cronies } \\
\text { gain, to } \\
\text { continually } \\
\text { maintain the status } \\
\text { quo }\end{array}$ \\
\hline $\begin{array}{l}\text { Policy } \\
\text { Legitimation }\end{array}$ & $\begin{array}{l}\text { Executive } \\
\text { through } \\
\text { majority of } \\
\text { toy parlia- } \\
\text { ment } \\
\text { members }\end{array}$ & $\begin{array}{l}\text { Obedience, a } \\
\text { little pretending } \\
\text { arguement, safe } \\
\text { position, taking for } \\
\text { granted. }\end{array}$ & $\begin{array}{l}\text { Government } \\
\text { (Executive), } \\
\text { members } \\
\text { Parliaments } \\
\text { and the people. }\end{array}$ & $\begin{array}{l}\text { Formality } \\
\text { (political reasons), } \\
\text { Replacement }\end{array}$ \\
\hline $\begin{array}{l}\text { Policy } \\
\text { Implementation }\end{array}$ & Executive & $\begin{array}{l}\text { Inconsistent, } \\
\text { tendentious, } \\
\text { abused, } \\
\text { inefficient, } \\
\text { uneffective. }\end{array}$ & $\begin{array}{l}\text { Government } \\
\text { (Executive), few } \\
\text { officials and cronies, } \\
\text { business, and the } \\
\text { people. Corruption, } \\
\text { collusion and } \\
\text { nepotism were lively. }\end{array}$ & $\begin{array}{l}\text { The executive has } \\
\text { a stronger position } \\
\text { compared to the } \\
\text { position of the } \\
\text { legislative and }\end{array}$ \\
\hline
\end{tabular}




\begin{tabular}{llll}
\hline & & & $\begin{array}{l}\text { judiciary } \\
\text { institutions. }\end{array}$ \\
$\begin{array}{l}\text { Policy } \\
\text { Evaluation }\end{array} \quad$ Executive $\quad \begin{array}{l}\text { just } \\
\text { inefficient, } \\
\text { uneffective, }\end{array}$ & $\begin{array}{l}\text { Government, offi- } \\
\text { cials and cronies, } \\
\text { business, and the } \\
\text { people. }\end{array}$ & $\begin{array}{l}\text { A little for public } \\
\text { interest. }\end{array}$ \\
\hline
\end{tabular}

Sources: GuruPendidikan.Com, 2020, Retorics , 2015, shentiald.blogspot.com/2013, empirical and observation during New Order Regime periode.

At that time, public policy process was under the control of Executive Body (Government). It happened to each stage of policy making starting from the formulation, legitimation, implementation, and to the evaluation. In Retorics (2015) it was stated that the position of the executive branch remained dominant. This side engineered the formulation, abused the implementation, was in charge of controlling. In policy formulation, this body tended to have done it carelessly. The legitimation of the proposed policy could be passed very smoothly because there was majority vote domination due to blind obedience. When it came to the implementation, it was full of conflict of interests. Finally, the evaluation was carried out perfunctorily and only to fulfill formality. In a political process like this, on the surface, everything looks just fine. In fact, the situation is not normal and can be a time bomb. The people cannot tolerate the situation anymore. The time bomb, finally, exploded and the new order collapsed. The political order must be normal and reasonable so that balance can be maintained and the institutions in government are independent. Trondal (2020) insisted political order consisted of a relatively stable arrangement of institutions that were fairly formalized and institutionalized. A common political order, moreover, entailed that relevant institutions: (i) were fairly independent of pre-existing institutions; (ii) were relatively integrated and internally cohesive; and (iii) were reasonably able to influence governance processes within other institutions.

Nowadays, the "flag" of regional autonomy is waving, the situation of public policy is still deeply saddened. It is neither efficient in the making nor effective in the implementation and the goals accomplishment. As long as public policy is concerned, the difference of the previous regime from the present one is on the actors. See the following table. 
Table 2.

The Description of The Characteristic of Public Policy in Regional Autonomy Era

\begin{tabular}{|c|c|c|c|c|}
\hline $\begin{array}{c}\text { Stages of Public } \\
\text { Policy }\end{array}$ & The Actor & Treatment & Benefit Receiver & Remark \\
\hline $\begin{array}{l}\text { Policy } \\
\text { Formulation }\end{array}$ & $\begin{array}{l}\text { Executive, but } \\
\text { sometimes } \\
\text { proposed by } \\
\text { Legislative. } \\
\text { Such as, draft } \\
\text { law on the } \\
\text { commission to } \\
\text { eradicate } \\
\text { corruption }\end{array}$ & $\begin{array}{l}\text { Comparative } \\
\text { study - rather } \\
\text { than research to } \\
\text { get the feasibility } \\
\text {-resulting in } \\
\text { inefficiency, } \\
\text { uneffectiveness. }\end{array}$ & $\begin{array}{l}\text { Political parties } \\
\text { through their members } \\
\text { in Parliament } \\
\text { (Legislative Body), } \\
\text { government, few (high } \\
\text { rank) office- als, and } \\
\text { the people. }\end{array}$ & $\begin{array}{l}\text { Personal/cronies } \\
\text { gain, } \\
\text { Power eternity for } \\
\text { MP (Legislative). }\end{array}$ \\
\hline $\begin{array}{l}\text { Policy } \\
\text { Legitimation }\end{array}$ & $\begin{array}{l}\text { Legislative } \\
\text { Body }\end{array}$ & $\begin{array}{l}\text { Heated debate, } \\
\text { walk out, no } \\
\text { agreement, but } \\
\text { most is meant not } \\
\text { for the ineterst of } \\
\text { the people. }\end{array}$ & $\begin{array}{l}\text { Political Parties and } \\
\text { their members in } \\
\text { parliament } \\
\text { (Legislative), The } \\
\text { people, government. }\end{array}$ & $\begin{array}{l}\text { To pass a bill, } \\
\text { bribery to members } \\
\text { of parliament (MP/ } \\
\text { Legislative) takes } \\
\text { place. One of the } \\
\text { changes in the } \\
\text { reform era, namely } \\
\text { strengthening the } \\
\text { role of the People's } \\
\text { Representative } \\
\text { Council (DPR) as a } \\
\text { legislative } \\
\text { institution (Dwi, in } \\
\text { Ekamara, 2015). }\end{array}$ \\
\hline $\begin{array}{l}\text { Policy } \\
\text { Implementation }\end{array}$ & $\begin{array}{l}\text { Executive in the } \\
\text { shadow of } \\
\text { Legislative }\end{array}$ & $\begin{array}{l}\text { Share power } \\
\text { unless } \\
\text { tight control but } \\
\text { sometimes for the } \\
\text { gain of } \\
\text { Legislative, not } \\
\text { mainly for the } \\
\text { people. }\end{array}$ & $\begin{array}{l}\text { Legislative (members } \\
\text { of parliament), cronies, } \\
\text { business, the people. }\end{array}$ & 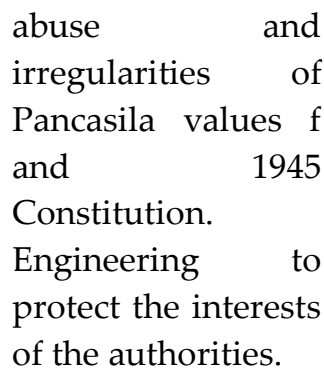 \\
\hline Policy Evaluation & $\begin{array}{l}\text { Legislative and } \\
\text { Executive }\end{array}$ & $\begin{array}{l}\text { Flowing and } \\
\text { depending on the } \\
\text { need, primarily, } \\
\text { of MP/ } \\
\text { Legislative } \\
\text { MP/ Legislative } \\
\text { usually more } \\
\text { active. }\end{array}$ & $\begin{array}{l}\text { Legislative (mainly, } \\
\text { the members of } \\
\text { parliament) }\end{array}$ & $\begin{array}{l}\text { Evaluation needed } \\
\text { or smoothly passed, } \\
\text { when it gives } \\
\text { benefits, primarily, } \\
\text { to MP/ Legislative }\end{array}$ \\
\hline
\end{tabular}

Sources: kompasiana.com/ekamara, 2015, JawaPos.com., 2019, GuruPendidikan.Com 2020,

djunedglow.blogspot.com, 2011, Situs pendidikan dan pembelajaran terbaik, 2020, empirical and observation during New Order Regime periode.

Table 2 above shows that - in its relation to public policy - Legislative body (House of Representative/Parliament) has become more active almost on all stages of public policy 
process. The fact that this body has more power, plays more roles, and controls excessively. Most the time, most members of parliament acts this way for financial gain, power stability, and popularity. The needs for the people are left behind. Incidents like this, make people lose their trust to their representatives in parliament. This encourages voters to stop electing members of parliament who are not mandated. In fact, there is a possibility that they will no longer wish to participate in the election. Rinfret, Sara and Christina Barsky (2020) added it is clear that local election administrators are inherently civic entrepreneurs because their interactions with citizens directly influences the publics' trust in electoral processes, and in turn, to their participation. In fact, according to Nijzink, Lia, Mozaffar, and Azevedo (2007) parliamentarians seem to be widely regarded as potential agents for democratic change but whether national legislatures are in fact enhancing the quality of democracy is far from clear. Actually, according to Czapanskiy and Manjoo (2018) by definition, a democratic nation has some mechanism through which leaders hear from the people. Ordinarily, the mechanism is a periodic election during which the people have an opportunity to hold leaders accountable. Between these traditional opportunities for democratic involvement, however, should a democratic nation have mandatory mechanisms for give and take between legislative leaders and the public. The diverse and more power that this body/Legislative has are as follows. See table 3.

\section{Table 3.}

\section{Power diversity of Legislative in Regional Autonomy Era}

\begin{tabular}{|c|c|c|}
\hline The Approving Body & Power Diversity & Remark \\
\hline Legislative & $\begin{array}{l}\text { National Budget and the use } \\
\text { approval. } \\
\text { Other additional budgets and } \\
\text { financial aids for special } \\
\text { developmental purposes. }\end{array}$ & $\begin{array}{l}\text { the executive branch is } \\
\text { overseen by the legislature. } \\
\text { many regional government } \\
\text { representatives approach and } \\
\text { bribe MPs for proposal } \\
\text { approval. }\end{array}$ \\
\hline Legislative & Bill Passing & $\begin{array}{l}\text { The tradisional function of } \\
\text { Legislative, Nowadays, many } \\
\text { sides: ministry, business, and } \\
\text { others bribe MPs to pass the } \\
\text { bill. }\end{array}$ \\
\hline Legislative & $\begin{array}{l}\text { High rank (civil and military) officers } \\
\text { appointment }\end{array}$ & $\begin{array}{l}\text { Used to be determined by } \\
\text { Executive Body only. Now, } \\
\text { proposed by Executive, but } \\
\text { approved by Legislative. As } \\
\text { the result, some candidates or } \\
\text { the supporters bribe the MPs }\end{array}$ \\
\hline
\end{tabular}




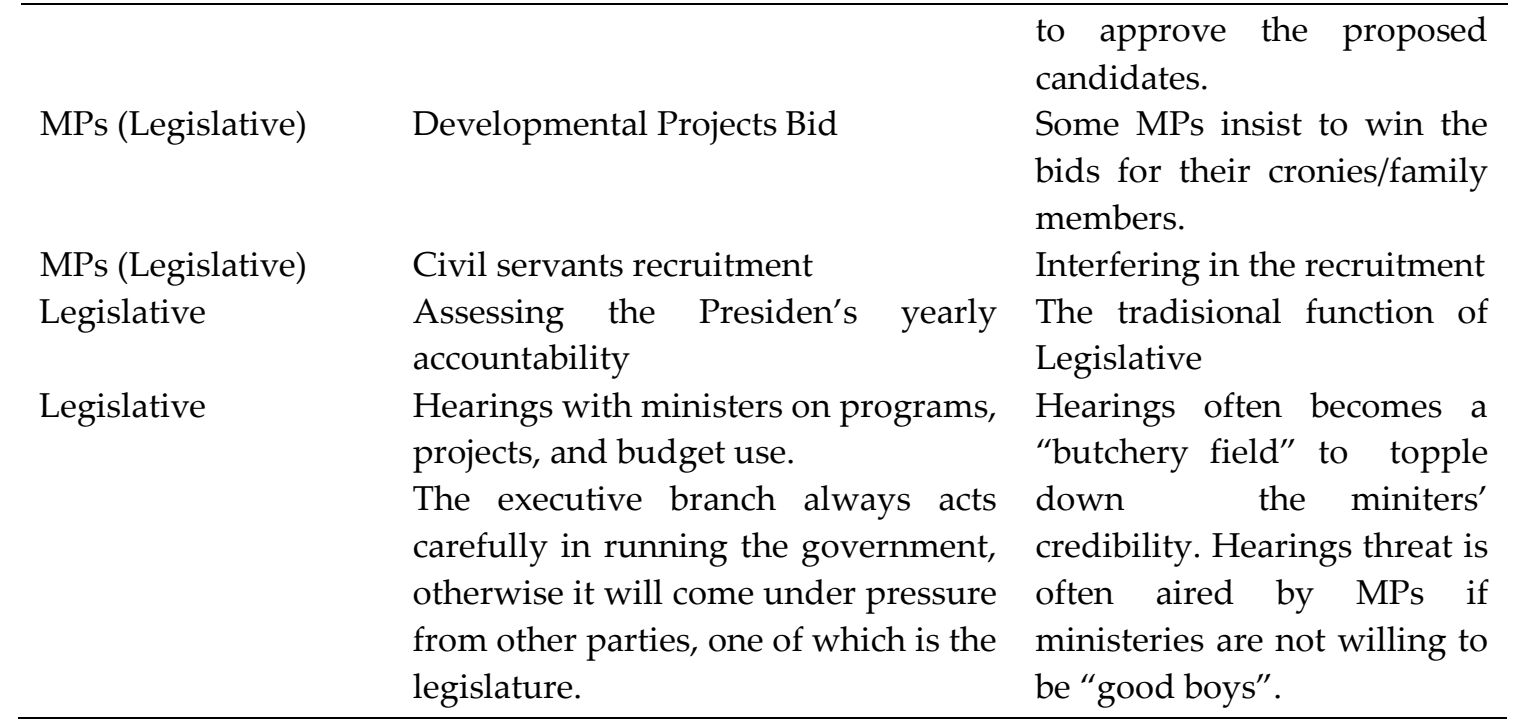

Sources: djunedglow.blogspot.com, 2011, xanthocephalus.wordpress.com/2012, empirical and observation during New Order Regime periode.

Data above indicate that Legislative body - in regional autonomy era - has become a hungry power body. This institution makes itself powerful by seizing the power from other sides and by abusing its own power. This condition causes incredulity towards this Body and many of the members get involved in wrongdoings and become prisoners. The greed of power hungry politicians who abuse their authorities can be revealed in many ways. One of them is through the role of the media. Dimova (2020) said "democracy, accountability, and media have a difficult relationship. It is hard to say whether media allegations levelled at government incumbents, and the subsequent investigations, and sanctions of these media allegations, benefit or undermine democracy. On the one hand, it is entirely possible that governing elites use media scandals as an opportunity to threaten opponents and deflects attention from unpopular politic. On the other hand, if the allegations are viable, when public benefits government offers more explanation, dismisses corrupt officials or reverses controversial policies". For more detail information, consult table 4 below.

Table 4.

Wrongdoings Relating to Public Policy Process

\begin{tabular}{lll}
\hline \multicolumn{1}{c}{ Wrongdoings } & Actor & \multicolumn{1}{c}{ Remark } \\
\hline Procurement bribery & Legislative & $\begin{array}{l}\text { a MP received a sum of 10 billions } \\
\text { Rupiahs as bribery for helping } \\
\text { business winning a bid in Qur'an } \\
\text { procurement for Dept. of Religion } \\
\text { affairs. (2012) }\end{array}$ \\
& & $\begin{array}{l}\text { 1) } \\
\text { Several the involved MPs have been } \\
\text { investigated and 1 MP has been }\end{array}$ \\
$\begin{array}{l}\text { Infra and supra structures } \\
\text { procurement bribery for 16 } \\
\text { public universities. }\end{array}$ & Legislative & \\
\hline
\end{tabular}




\begin{abstract}
jailed. 600 billions Rupiah used to bribe the MPs. ${ }^{2}$

Steam electricity power plant

Legislative

Suspected that a MP accused to

development in Tarahan have received 300.000 US\$ as

Lampung.

Relating to the development bribery. ${ }^{3)}$

of a harbor in Tanjung Api-api

Legislative

Several MPs were jailed and

South Sumatera.

Bribery to pass a candidate of

Indonesia Central Bank

Legislative suspended as MP. Ex Governor of South Sumatera also was jailed.

Deputy. Several MPs, a business woman, and the Deputy candidate were jailed.

Sources: ${ }^{1)}$ Kompas, Saturday, September 8, 2012, Page 4, ${ }^{2}$ Kompas, Wednesday, June 6, 2012, page 7,

3) Kompas, Tuesday, August 28, 2012, page 2.

The above information was just some examples showing the wrongdoings usually done by the members of Legislative Body. The members could and dared to have done those sins because institutionally, the Body had become much stronger and had excessive power. The usual forms of abuse of power by politicians are related to the approval of proposed projects and the placement of high-ranking officials in certain positions. In this context, the mistakes made by these MPs - by type - were three. Namely, the interference of the executive officials' authority, abuse of power, and financial losses to the state and the people through the bribes they receive.
\end{abstract}

\title{
The Impacts of Transformation in Public Policy Affairs
}

Transformation did happen in public policy affairs. In new order regim, as long as public policies were concerned, Executive body proposed, directed and controlled the legitimation, did the implementation as well as the evaluation to them. Functionaries, businessmen, and cronies abused power and obtained a lot of benefits. The people were left behind, hopless, and stayed poor. This state body "forgots" the values of Pancasila and the 1945 Constitution. Therefore, the glimmer of hope for the welfare of the Indonesian people faded away.

However, after struggling against the impartiality of the New Order regime, there was born reformed era. During this period, regional autonomy was proposed, recognized and implemented. Traumatized by power domination of executive body, the people presented by the parliamentarians in Legislative agency wanted some policies be revised and modified. It could be done well. But unfortunately, this actually changed the direction of power 
domination. The members of parliament tended to have more power. Power direction shifted from executive to legislative.

When the direction of power rested more on the part of the legislature, hopes for a better life for the people arouse again. At first, the point of brightness looked pretty clear, in progress, but it was ultimately gloomy again. Parliamentarians were busy taking care of their personal and crony interests rather than the welfare of the people. The people were disappointed again, depressed again, and still poor again.

\section{Parting Words}

There exists a dynamic in the process of public policy making in democratic Indonesia. This dynamic undergoes a transformation, both in its relation to the regime in power, the more role of the state bodies, and the interests that are being fought for. Dynamic transformation, basically, takes place, but people's welfare has not improved. It, even, tends to be worse.

\section{References}

Alfatih, A. (2010). Implementasi Kebijakan dan Pemberdayaan Masyarakat. Bandung: Unpad Press.

Alfatih, A. (2012). The Failure of Policy Implementation in Indonesia and The Breaktrough. International seminar and conference on innovative government. Malang: Universitas Brawijaya.

Alfatih, A. (2013). Is Regional AUtonomy A Paradox. Public Administration Journal, 1(1), 110.

Czapanskiy, K., \& Manjoo, R. (2008). The Right of Public Participation in the Law-Making Process and the Role of the Legislature in the Promotion of this Right. Duke Journal of Comparative \& International Law, 19(1). Retrieved from https://scholarship.law.duke.edu/djcil/vol19/iss1/1

Dimova, G. (2020). Democracy Beyond Elections Government Accountability in The Media Age. Newyork: Palgrave Mc. Millan.

Djunet, H., \& Muhammad, I. (2011). Eksekutif dan Legislatif Orde Lama, baru dan Reformasi. Retrieved from https://djunedglow.blogspot.com/2011/12/eksekutif-dan-legislatiforde-lama-baru.html 
Held, D. (1990). Models of Democracy. Oxford: Polity Press.

News, R. (2015). Lembaga Eksekutif: Dari oder Lama Hingga Era Reformasi. Retrieved from https://retorics.blogspot.com/2015/02/lembaga-eksekutif-dari-orde-lama-hingga-erareformasi.html.

Nijzink, L., Mozaffar, S., \& Azevedo, E. (2006). Parliaments and the enhancement of democracy on the African continent: An analysis of institutional capacity and public perceptions. Journal of Legislative Studies, 12(3-4), 311-335. http://doi.org/10.1080/13572330600875563

Nugroho, R. (2009). Public Policy. Jakarta: Elex Media Komputindo.

Osborn, D., \& Gabler, T. (1993). Reinventing Government. New York: Plume House Publishing.

Pendidikan, D. (2020). Pennyimpangan Orde Baru. Retrieved from Dunia Pendidikan: Situs dan Pembelajaran Terbaik: https://dunia.pendidikan.co.id/penyimpangan-orde-baru/

Pos, J. (2019). Beda Pendapat DPR dengan Abraham Samad terkait Revisi UU KPK. Jakarta, Jakarta, Jakarta.

Putri, A. S. (2020). Karakteristik Demokrasi Periode Oder Baru. Retrieved from https://www.kompas.com/skola/read/2020/02/13/110000969/karakteristik-demokrasiperiode-orde-baru.

Rinfret, S., \& Barsky, C. (2020). The Gatekeepers of US Elections: Exploring Street Level Bureaucrats in Montana. International Journal of Public Administration, 43(16), 13571365. http://doi.org/10.1080/01900692.2019.1669173

Setiawan, P. (2020). Sejarah Orde Baru. Retrieved from GuruPendidikan.Com

Shentia, L. D. (2013). Kekurangan Sistem Pemerintahan Orde Baru. Retrieved from https://shentiald.blogspot.com/2013/12/makalah-indonesia-pada-masa-ordebaru.html

Trondal, J. (2020). Public Administration and the Study of Political Order: Towards a Framework for Analysis. Politics and Governance, 8(4), 451-461. http://doi.org/10.17645/pag.v8i4.3264

Xanthocephalus. (2012). Badan Legislatif pada Masa Orde Baru dengan Masa Reformasi. Retrieved from https://xanthocephalus.wordpress.com/2012/07/01/badan-legislatifpada-masa-orde-baru-dengan-masa-reformasi/. 